\title{
Building sensory receptors on the tongue
}

\author{
BRUCE OAKLEY ${ }^{1}$ and MARTIN WITT ${ }^{2, *}$ \\ ${ }^{1}$ Department of Molecular, Cellular, and Developmental Biology, University of Michigan, Ann Arbor, Michigan, 48109; ${ }^{2}$ Department of \\ Anatomy, University of Technology Dresden, and Center for Smell and Taste, Medical School, 01307 Dresden, Germany \\ mwitt@rcs.urz.tu-dresden.de
}

Received 8 February 2005; accepted 5 April 2005

\begin{abstract}
Neurotrophins, neurotrophin receptors and sensory neurons are required for the development of lingual sense organs. For example, neurotrophin 3 sustains lingual somatosensory neurons. In the traditional view, sensory axons will terminate where neurotrophin expression is most pronounced. Yet, lingual somatosensory axons characteristically terminate in each filiform papilla and in each somatosensory prominence within a cluster of cells expressing the p75 neurotrophin receptor (p75NTR), rather than terminating among the adjacent cells that secrete neurotrophin 3 . The p75NTR on special specialized clusters of epithelial cells may promote axonal arborization in vivo since its over-expression by fibroblasts enhances neurite outgrowth from overlying somatosensory neurons in vitro. Two classical observations have implicated gustatory neurons in the development and maintenance of mammalian taste buds- the early arrival times of embryonic innervation and the loss of taste buds after their denervation in adults. In the modern era more than a dozen experimental studies have used early denervation or neurotrophin gene mutations to evaluate mammalian gustatory organ development. Necessary for taste organ development, brain-derived neurotrophic factor sustains developing gustatory neurons. The cardinal conclusion is readily summarized: taste buds in the palate and tongue are induced by innervation. Taste buds are unstable: the death and birth of taste receptor cells relentlessly remodels synaptic connections. As receptor cells turn over, the sensory code for taste quality is probably stabilized by selective synapse formation between each type of gustatory axon and its matching taste receptor cell. We anticipate important new discoveries of molecular interactions among the epithelium, the underlying mesenchyme and gustatory innervation that build the gustatory papillae, their specialized epithelial cells, and the resulting taste buds.
\end{abstract}

\section{Introduction}

A long line of studies supports the nerve-dependent development of mammalian secondary sense organs-those specialized peripheral cells that are innervated by primary sensory neurons (Zelena, 1994). The classical evidence relied partly upon careful descriptions of timing-receptor organs develop only after nerve fibers arrive. Novel experimental methods have recently substituted genetic surgery for reliance upon the daunting difficulties of embryonic surgery. As a result, an abundance of data from induced mutant mice has now certified the classical view for profound influences of sensory innervation upon the development and differentiation of secondary sensory cells. Induced mutations of neurotrophin genes have been particularly instructive. Neurotrophins are structurally related, secreted proteins that exert critical influences on nervous system function and development. The four mammalian neurotrophins, nerve growth factor (NGF), brain-derived neurotrophic factor (BDNF), neurotrophin-3 (NT3), and neurotrophin-4 (NT4), are traditionally viewed as target-derived survival factors that sustain developing neurons whose axons navigate to the target tissue. The terminals of these axons bear receptor tyrosine kinases (TrkA, TrkB, or TrkC) that bind cognate neurotrophins secreted in the target tissue. Of particular relevance, NT3 binds to TrkC, whereas BDNF, NT4 and, to a lesser extent, NT3 bind to TrkB. Additionally, all four neurotrophins bind well to a fourth receptor, the p75 neurotrophin receptor (p75NTR). Since neurotrophins provide crucial support for developing sensory neurons, many research groups have examined the phenotype of mice with a null mutation for a neurotrophin or a neurotrophin receptor gene. For example, the absence of NT3 causes the widespread death of embryonic proprioceptive neurons whose loss in turn prevents muscle spindle development (Lee et al., 1992; Enfors et al., 1994). Such compelling observations have heightened interest in the development of other secondary sense organs, including taste buds.

* To whom correspondence should be addressed. 
This review recognizes three important stages in mammalian taste bud development: an early period that establishes the location and competence of taste papillae, sensitive periods when innervation is required for papilla maturation and the initiation of taste bud formation, and a final period of the proliferation and functional differentiation of taste receptor cells. It is timely to consider recent applications of molecular genetics that have identified some of the molecular factors allowing innervation to contribute to the differentiation of taste receptor cells from local oral epithelium.

Current understanding of gustatory molecular receptors and channels engaged by tastants has been reviewed elsewhere (Montmayeur \& Matsunami, 2002; Bigiani et al., 2003; Gilbertson \& Boughter, 2003; Kim et al., 2004). Farbman (2003) has recently considered the diverse potential roles of BDNF and related neurotrophins in taste bud function. Here we highlight recent studies of the neurotrophic support of lingual somatosensory organs, and then more extensively we evaluate findings on the development of mammalian taste organs.

\section{NT3 and p75NTR support lingual somatosensory function}

Although more notable for its prominent gustatory papillae, the tongue's surface also contains a remarkably dense deployment of somatosensory receptors. Detailed spatial information in mice is generated by the displacement of clusters of evenly dispersed filiform papillae, each innervated by a small bundle of axons. In humans the great sophistication of the comparable lingual mechanosensory system may enable some astonishing clinical advances. A pixel-like array of 49 stimulating electrodes can generate lingual action potentials in unique temporal-spatial patterns that can partially compensate for a patient's severely diminished input from vestibular organs or from the retina (Tyler et al., 2003).

The sites of pronounced touch sensitivity in the mouse tongue can be visualized with staining that relies on a lacZ reporter gene for NT3 expression (Fariñas et al., 1994). Our recent studies on lacZ-NT3 mice (Fan et al., 2004; Fig. 1) marked the blue-colored location of every filiform and fungiform papilla, while at the back of the tongue NT3 expression is notable in the foliate and vallate papillae and in a newly identified class of touch organs, the somatosensory prominences (initially described as "circumvallate plates" by Nosrat et al., 1997). Both NT3 and p75NTR are important in the development and maintenance of lingual somatosensory receptors. For example, NT3 supports the expression of p75NTR by epithelial cells near the base of each filiform papilla (Fan et al., 2004). In turn, the developmental survival of the small bundle of somatosensory axons that innervates a filiform papilla requires both
NT3 and p75NTR (Nosrat et al., 1997; Fan et al., 2004). Remarkably, it was apparent in all filiform papillae and somatosensory prominences that the somatosensory axons failed to obey their traditionally assigned role of terminating at the site of the most intense NT3 expression. Instead, the somatosensory axons invariably terminated less superficially, within the cluster of p75NTR-positive cells (Fig. 1b, c). We hypothesized that as NT3 diffuses, it binds to the p75NTR exposed on the surface of nearby target cells, indirectly prompting the somatosensory axons to expand their terminal arbors. Cell culture experiments supported the principle of this concept by demonstrating that after trigeminal sensory neurons were seeded onto a lawn of fibroblasts engineered to express p75NTR under doxycycline control, neurite outgrowth more than doubled compared with matched control cultures of fibroblasts that expressed minimal p75NTR (Fan et al., 2004).

\section{Anatomy of rodent peripheral taste organs}

Mammalian taste buds are clusters of elongated neuron-like epithelial cells, many of which have synapse-like contacts with gustatory axons (Figs. 2, 3 and see Witt et al., 2003). In addition to residing in lingual papillae, taste buds are also located in the epithelium of the epiglottis, pharynx, and palate. The trench walls of the solitary vallate papilla at the back of the adult mouse tongue contain more than 120 taste buds, most of which are bilaterally innervated by the glossopharyngeal nerve (Cooper \& Oakley, 1998). The anterior two thirds of the mouse tongue is covered by thousands of somatosensory filiform papillae, each extending a prominent spine (Figs. 1 and 3a; Nosrat et al., 1996). Interspersed among the filiform papillae are loose anterior-posterior rows of more than 130 domed fungiform papillae that contain solitary taste buds. The fungiform papillae are innervated by both the chorda tympani nerve and the lingual nerve that merge to form the chordalingual nerve complex which enters the tongue (Fig. 2). Within the papilla, the incoming nerve fibers segregate into chorda tympani neurons, which innervate taste buds, and trigeminal neurons, which are predominantly in the surrounding non-gustatory epithelium (Fig. 3b). As will be discussed, specific neurotrophins in embryonic gustatory papillae support the gustatory neurons.

\section{The development and maintenance of gustatory papillae}

Research on mammalian gustatory organ development has progressed from descriptive studies on the development of papillae and taste buds to evaluations of the dependence of these structures upon innervation (tabulated in Ganchrow \& Ganchrow, 1989). The emergence and spatial pattern of the gustatory papillae anlage are 


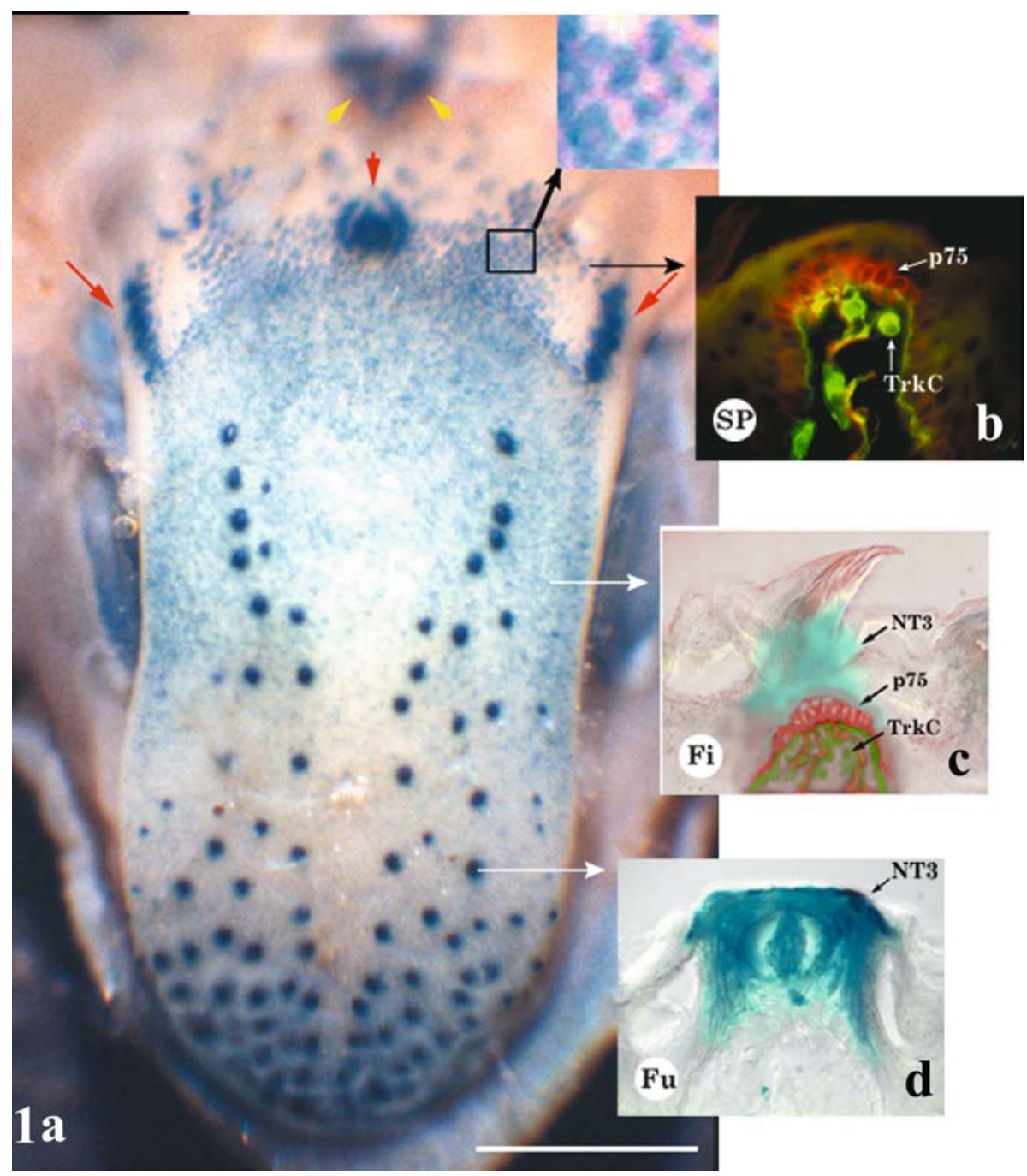

Fig. 1. P75NTR expression patterns are shown for postnatal mouse tongue. (a) The dorsal surface of the tongue of a P1 NT3(lacZneo)/+ mouse was photographed while attached to the mandible. LacZ staining shows NT3 expression (blue) is widespread in the tongue and pharynx. The epiglottis (yellow arrowheads), the vallate papilla on the midline (red arrowhead), the foliate papillae (red arrows) and rows of numerous dispersed fungiform papillae are all NT3-positive. The outline square enclosing several somatosensory prominences near the vallate papilla is enlarged (heavy black arrow). (b) The section through a typical adult dome-shaped somatosensory prominence (SP) depicts the immunostaining for p75NTR (red) and TrkC (green). The TrkC-positive areas included the basal lamina, scattered cells, and axon fascicles restricted to the core of the somatosensory prominence. P75NTR-positive axons terminated on basal and suprabasal cells that were p75NTR positive and TrkC-negative. (c) The section through a wild-type P7 filiform papilla (Fi) shows the locations of p75NTR (red) and TrkC immunoreactivities (green) in relation to schematically superimposed NT3 expression (blue). (d) The cross-section through a P21 taste bud-bearing fungiform papilla $(\mathrm{Fu})$ reveals the intense NT3 LacZ reactivity associated with the top and sides of the papilla. The scale bar with the tongue (a) is $1 \mathrm{~mm}$ and is $60 \mu \mathrm{m}$ for the insets (b) and (c) and $50 \mu \mathrm{m}$ for inset (d) (after Fan et al., 2004).

established prior to robust innervation (humans: Witt \& Reutter, 1996,1998). The early arrival of scattered axons makes it difficult to exclude completely a formative role for nerve fibers; some sensory nerve fibers approach the mesenchyme of mouse tongue anlage as early as E11 (Oakley, 1998). The cessation of papilla development in tongue organ cultures lacking innervation (Farbman \& Mbiene, 1991; Mbiene et al., 1997), and particularly tellingly, the stunting and distortions of sparsely innervated developing papillae in $b d n f$ and $t r k B$ knockout mice (Nosrat et al., 1997; Zhang et al., 1997; Oakley et al., 1998; Mistretta et al., 1999; Sun \& Oakley, 2002) collectively indicate that innervation is required for the sustained maturation of fungiform, foliate, and vallate papillae, but little or not at all for the nasopalatine papilla (Cooper \& Oakley, 1998). In a dramatic testimonial to the continued importance of innervation, postnatal interruption of the chordalingual nerve complex can convert a fungiform papilla into a filiform-like papilla, the apparent default state in the absence of neonatal gustatory innervation (Hård af Segerstad et al., 1989; Oakley et al., 1990; Nagato et al., 1995). 


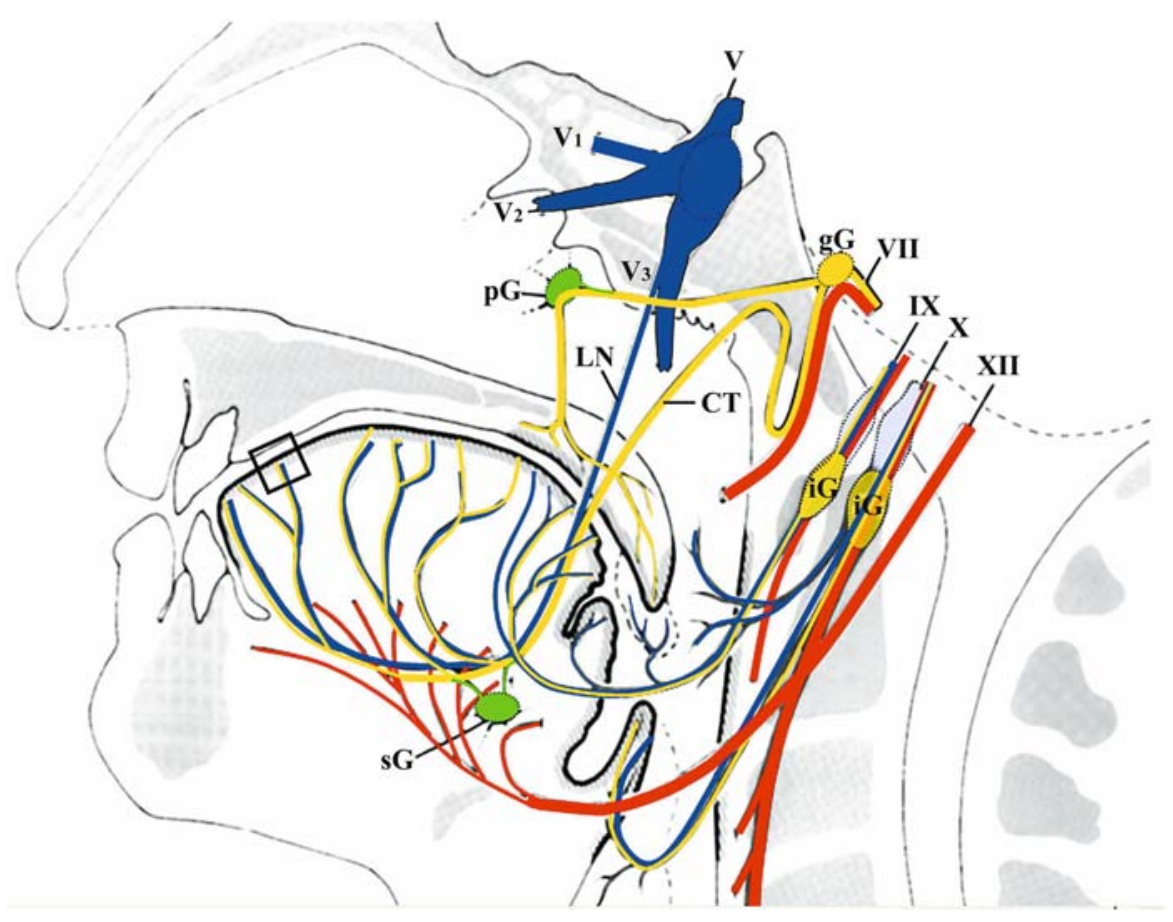

Fig. 2. Schematic overview of the innervation of the tongue and taste bud-bearing epithelia. Gustatory nerve fibers (shown in yellow) derive from cranial nerves (CN) VII (facial-intermediate nerve complex), IX (glossopharyngeal nerve), and X (vagal nerve). Their first perikarya are located in the local ganglia: The geniculate ganglion (gG; afferents from the facial-intermediate complex with the branches chorda tympnani, CT, and the greater petrosal nerve, which supply taste buds of the anterior third of the tongue and palate taste buds and uvula, respectively), inferior ganglion (iF) of CN IX (taste buds of the posterior third of the tongue of vallate and foliate papillae) and iF of CN X (taste buds of the pharynx). Somatosensory nerve fibers (shown in blue) accompany gustatory fibers and innervate epithelial sections surrounding taste buds. The lingual nerve (LN) travels with the CT and innervates non-gustatory epithelium of fungiform papillae; somatosensory fibers of CN IX supply non-gustatory areas of vallate and foliate papillae. A detailed view of the ramification of CT and lingual nerve terminals on fungiform papillae (rectangle on the anterior part of the tongue) is shown in Fig. 3b. The ophthalmic nerve (V1) and maxillary nerve (V2, with fibers that innervate the palate) are truncated. sG, submandibular ganglion (green) with postganglionic autonomic (parasympathetic) nerve fibers of the CT to supply the submandibular and sublingual glands. pG, pterygopalatine ganglion (green) with postganglionic parasympathetic fibers of the greater palatine nerve to supply the lacrimal gland. Both ganglia have no synaptic connection with gustatory nerve fibers. Motor nerves (shown in red): XII, hypoglossal nerve to supply intrinsic tongue muscles; motor branches of CN VII and CN IX are truncated (adapted after Witt et al., 2003 ).

\section{Classical assessments of the development and maintenance of mammalian taste buds}

The study of the nerve-dependency of mammalian taste buds has a venerable history (Oakley \& Benjamin, 1966). It has been known since the late 19th century that adult taste buds disintegrate after interruption of their nerve supply (von Vintschgau \& Hönigschmied, 1877). By the 1940s it was well established that mammalian taste buds degenerated when denervated but would regenerate if reinnervated. The canonical temporal sequence of the arrival of innervation prior to taste bud development is clearly evident in human embryos where the gustatory axons first arrive at 7 weeks followed at 8 weeks by maturing papillae and differentiating taste cells identified by various markers (e.g., Witt \& Reutter, 1996, 1998; Witt \& Kasper, 1998, 1999). It was not until 1987 that experimental studies demonstrated the necessity of innervation in mammalian taste bud de- velopment (Hosley et al., 1987a, b). These experiments exploited the postnatal development of rat vallate taste buds and their bilateral innervation (Hosley \& Oakley, 1987). In the absence of vallate innervation from postnatal day 3 (P3), more than $80 \%$ of the hundreds of vallate taste buds simply failed to appear, even in an immature state. Compelling evidence for an influence of innervation included the four fold increase in the number of vallate taste buds following just a two fold experimental increase in the number of innervating axons. Such analyses indicated that the abundance of developing taste buds is a function of innervation density during a sensitive period (Hosley et al., 1987a, b). These experimental data showing the nerve-dependency during development of mammalian taste buds met with ready acceptance in part because they reaffirmed the prevailing view. Thus, a century of studying taste buds coalesced into one simple conclusion: mammalian taste buds require innervation to develop (Oakley, 1993a, 1998). 

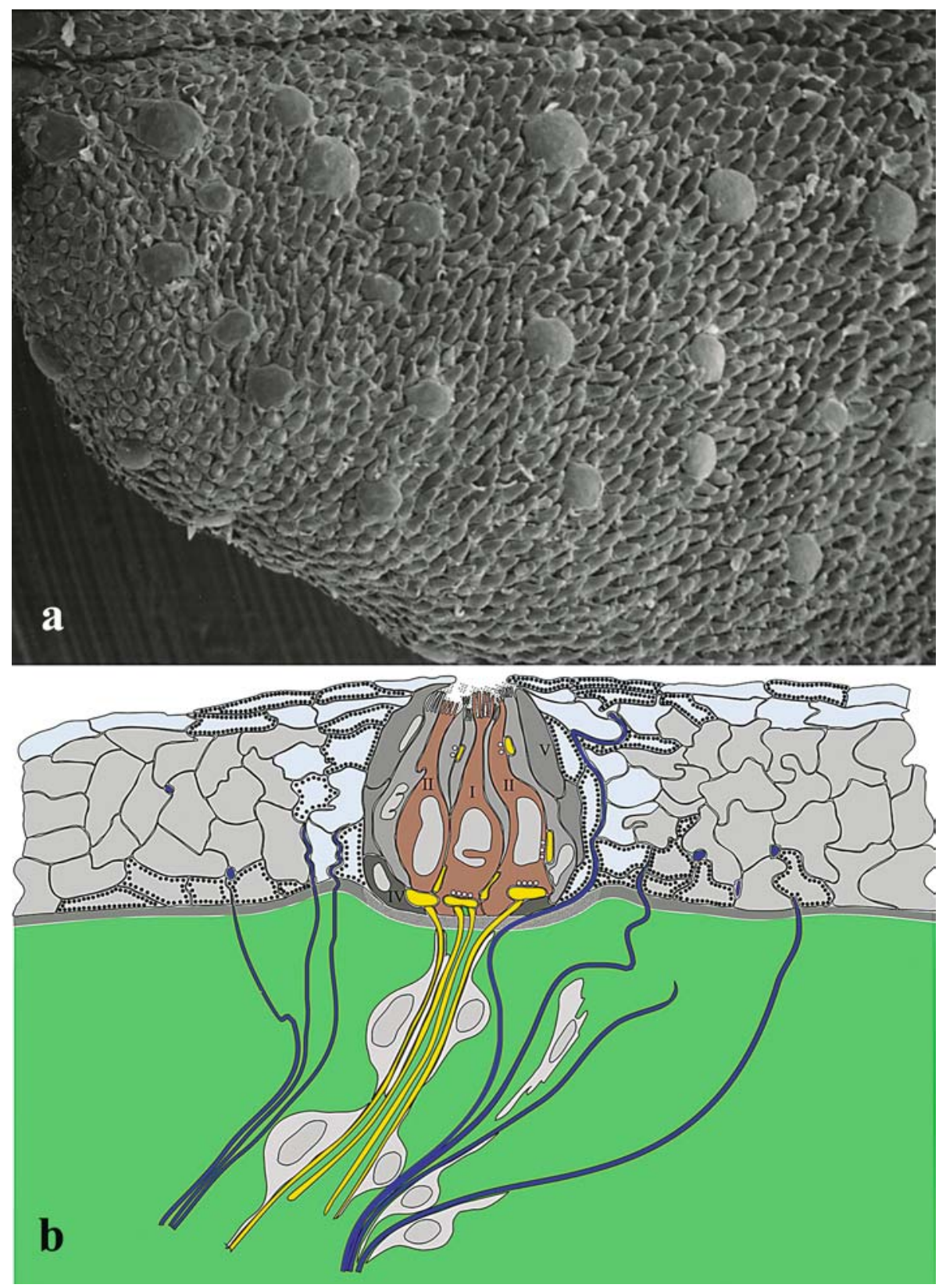

Fig. 3. (a) The scanning electron micrograph of the dorsal tip of a P7 mouse tongue shows more than 20 circular fungiform papillae scattered among thousands of filiform spines (courtesy of Dr. C.A. Nosrat, Univ. of Michigan, Ann Arbor). (b) In the schematic representation of a fungiform taste bud (rectangle in Fig. 2), BDNF-expressing taste cells (brown) are innervated by gustatory chorda tympani axons (yellow). Many of the cells surrounding the taste bud are innervated by somatosensory, lingual nerve axons (blue) and express NT3 (light blue) and p75NGFR (dots). Types of taste bud cells (I-V) according to Reutter and Witt (1993).

Recently, new approaches have allowed re-examination of the importance of innervation for peripheral gustatory development in mammals.

\section{The gustatory capabilities of non-gustatory epithelia and non-gustatory nerves}

It is a simple truism that from fertilization onward a complex series of molecular steps is required for the morphogenetic development of lingual tissues, including the specialized gustatory epithelia. Every experimental attempt to elicit taste bud formation from nongustatory tissues has failed, presumably because these tissues lack some essential developmental transformations that normally precede the arrival of nerve fibers (Oakley, 1993a; Krimm et al., 2001). The competence of denervated tissue may fail after a brief absence of glossopharyngeal neurons that permanently impairs the 
ability of the neonatal vallate epithelium to respond to gustatory re-innervation (Oakley, 1993b). The conclusion that taste buds can form de novo in filiform papillae turned out to be a misinterpretation of results of organ cultures (Zalewski, 1972). The correct interpretation is that a denervated fungiform papilla, retaining an atrophic taste bud, sometimes mimics a filiform papilla after it extends a spine-like outgrowth (Hård et al., 1989; Oakley et al., 1990, 1993; Nagato et al., 1995). Nerves with abundant gustatory axons (chorda tympani, glossopharyngeal, vagus, and the greater superficial petrosal nerves) can substitute for one another in mediating taste bud regeneration. Carotid body chemosensory (glossopharyngeal) neurons also appear to be able to elicit taste bud re-formation (Dinger et al., 1985). However, substituting motor axons, non-lingual somatosensory axons, and other non-chemosensory axons for gustatory axons has proven to be fruitless in eliciting the re-formation of mammalian taste buds (Oakley et al., 1990; Montavon et al., 1996). The consensus is that somatosensory fibers of the lingual nerve (trigeminal) are at best marginally effective in supporting taste buds.

\section{TASTE BUDS IN FISH AND AMPHIBIANS}

There are only a few recent studies on the development of fish taste buds. Hansen et al. (2002) described the appearance of the first oral taste buds in zebrafish 3-4 days after fertilization, but correlations between taste bud development and invasion of nerve fibers were not determined. Using calretinin as an early marker, Northcutt (2005) observed the first external taste bud primordia in a catfish only shortly after branches of the recurrent facial nerve were detected.

In the most complex vertebrate taste organ, the frog taste disk, Toyoshima et al. (1999) assigned the Merkel cell rather than nerves as the element more responsible for taste organ morphogenesis. Merkel cells are not present in mammalian lingual gustatory papillae.

When classical experimental embryology discovered that various cultured pieces of early Ambystoma embryos gave rise to nerve cells, it indicated that portions of the dorsal ectoderm had already committed to a neural fate even before the end of gastrulation. Indeed, in investigating the post-neurula emergence of taste buds well over a half a century ago, L. S. Stone was so impressed by the developmental autonomy of transplanted tongue fragments that he concluded "... [salamander taste bud] development is entirely independent of any reaction on the part of nerve fibers which might grow in ..." (Stone, 1933). The resilience of transplanted urodele taste buds (Wright, 1964) was not unexpected given the ability of urodeles to re-grow an entire amputated leg (Brockes, 1997). The mid-1990s witnessed a re-affirmation and elaboration of this long dormant conclusion that urodele taste buds were nerve-independent. Using specification assays, selective staining of taste cells, and confocal microscopy Barlow et al. (1996) and Barlow and Northcutt (1997) persuasively demonstrated that Stone was correct-the ingrowth of nerve fibers is unnecessary for the development of Ambystoma taste buds. Similarly, by the early neurula stage, presumptive oral tissue is already specified to develop taste receptor cells (Barlow, 1999).

Were it not for inhibition by bone morphogenetic proteins (BMPs), most ectodermal cells would become some type of nerve cell by default. Interestingly, Ambystoma has a notably low threshold for such neurulation. Thus, even without any invading axons, it may be that spots of BMP antagonists like noggin permit taste receptor neurons to form within cultured fragments of ectoderm. It should be possible to determine the sensitivity of salamander taste bud development to tissue culture conditions by varying the concentrations of BMPs and their antagonists. Until modern molecular analyses chart new paths, it is likely that the nervefree development of urodele taste buds will persist as a classical embryological mystery that only faintly informs research studies on mammalian taste bud development.

Based on work with urodeles, Northcutt and Barlow (1998) proposed the existence of a uniform vertebrate plan in which taste buds would develop freely without innervation. Their model suggests that the oropharyngeal epithelium undergoes modifications as early as gastrulation and that taste bud anlagen form by localized cell-cell interactions (Barlow \& Northcutt, 1998). As it turned out, their conjecture arrived on the cusp of innovative genetic interventions able to decrease, increase, or deflect gustatory innervation in embryonic mice. These recent experiments have provided fresh opportunities to evaluate whether mammalian taste buds require innervation to develop. As discussed extensively below, a surge of new and diverse correlative and experimental studies have reaffirmed that virtually all mammalian taste buds require innervation for their development.

\section{Recent observations on the temporal correlation between innervation and the subsequent development of taste buds in mammals}

Five cytokeratins $(\mathrm{CK} 7,8,18,19$, and 20) are referred to as "simple cytokeratins" because they are characteristically synthesized by simple epithelial cells (one cell layer thick); they are not expressed by stratified epithelial cells (several cell layers thick). During the perinatal period rat and human cytokeratins $7,8,18$, 19 , and 20 in the tongue are restricted to taste receptor cells and salivary duct cells which usually can be distinguished by cell shape and position (Sawaf et al., 1991; Knapp et al., 1995; Zhang et al., 1995; Zhang \& Oakley, 1996; Ganchrow, 2000). That is why antibodies against these particular cytokeratins have been practical 
markers of gustatory cells. Indeed, lingual CK20 expression is wholly restricted to taste buds (Zhang \& Oakley, 1996; Witt \& Kasper, 1999). CK20 was particularly effective in demonstrating that innervation preceded the differentiation of human taste receptor cells (Witt \& Kasper, 1999).

The tight temporal progression from innervation to the initial development of taste buds is not limited to lingual taste buds. For example, the first sensory axons to invade the apex of the rat nasopalatine papilla enter at E17 and are followed by the appearance of immature taste buds at that site no later than E19. It is not until E20 that nerve fibers invade the wall of the nasopalatine duct where immature taste buds are first observed at P1 (El-Sharaby et al., 2004).

The adult gustatory system also retains a latent capacity to form additional taste buds in response to additional innervation. Collectively the glossopharyngeal nerve and the posterior branch of the chordalingual nerve complex support a mean of 133 taste buds in the foliate papillae of the adult Mongolian gerbil. Surgically directing the entire chordalingual nerve toward the foliate papillae boosted the number of foliate taste buds by $25 \%$ to 167 (Riddle et al., 1987).

\section{An overview of multiple experimental evaluations of the role of innervation in mammalian taste bud development}

The hypothesis that mammalian taste buds will develop without embryonic innervation has failed to receive support from more than a dozen recent experimental studies. The experimental strategies used to disrupt developing lingual innervation and thwart taste bud development include surgical denervation (Hosley et al., 1987a,b; Nagato et al., 1995), chemical denervation (Morris-Wiman et al., 1999), depletion of BDNF-dependent oral innervation (Nosrat et al., 1997, 2000; Zhang et al., 1997; Oakley et al., 1998, Mistretta et al., 1999), depletion of TrkB-dependent lingual innervation (Fritzsch et al., 1997; Zhang et al., 1997), depletion of p75NTR-dependent lingual innervation (Fan et al., 2004), the double knockout of the bdnf and $n t 3$ genes (Nosrat et al., 2005), and the termination of TrkBdependent innervation in non-gustatory sites owing to ectopic expression of BDNF or NT4 (Ringstedt et al, 1999; Krimm et al., 2001). These many studies demonstrate that rat and mouse taste buds develop only in the presence of gustatory innervation, with a subset of fungiform taste buds as a possible exception (see Fritzsch et al., 1997 below) Correspondingly, hyperinnervation increases the number of taste receptor cells during development (Zeng et al., 2000) and increases the number of taste buds in adults (Riddle et al., 1987). We now examine, in the requisite detail, critical studies of mammalian taste bud development.

\section{Neural control of vallate taste bud development}

Observations on the spatial expression of neurotrophin mRNA suggested that BDNF supports gustatory neurons, whereas NT3 supports somatosensory neurons (Nosrat \& Olson, 1995; Nosrat et al., 1996, 2001). Accordingly, TrkB-immunopositive axons have been linked to the development and regeneration of vallate taste buds (Kim et al., 2003), as predicted by the presumption that gustatory axons must bear TrkB receptors that can bind BDNF, NT3, and NT4. By the mid 1990s it became evident to several research groups that the null mutation of the appropriate neurotrophin gene might act as a form of genetic surgery to denervate embryonic mouse tongues and impair taste organ development. Null mutation of either $\operatorname{trk} B$ or $b d n f$ resulted in a sparsely innervated vallate papilla that was stunted and had few, if any, taste buds (Nosrat et al., 1997; Zhang et al., 1997; Cooper \& Oakley, 1998; Oakley et al., 1998; Mistretta et al., 1999). Quantitatively, the reduced density of gustatory innervation among $b d n f^{-/-}$mice explains about $90 \%$ of both the variance in the number of taste buds and the variance in the area of the gustatory epithelium (Oakley et al., 1998). Those vallate gustatory trenches that developed with no innervation had no taste buds (Zhang et al., 1997; Oakley et al.,1998). The complete absence of vallate innervation and taste buds in $b d n f / n t 3$ double null mutant mice is a more severe defect than the partial losses in $b d n f$ null mutant mice (Nosrat et al., 2005). It is likely that in the double null mutant mice the knockout of $n t 3$ not only eliminated many TrkC somatosensory neurons but also ensured elimination of any residual gustatory innervation rescued by NT3 in $b d n f^{-/-}$vallate papillae (Cooper and Oakley, 1998). Embryonic development must have been defective because newborn $b d n f^{-/-}$mice had stunted and sparsely innervated vallate papillae deficient in taste buds. Furthermore, because $b d n f^{-1-}$ fetal tongues had few taste buds at all times, there could not have been a fetal upsurge in taste buds followed by their disappearance by birth (Cooper \& Oakley, 1998; Oakley et al., 1998; Zeng et al., 2000). Whether one examined the fewer than $20 \%$ of the vallate taste buds that arise prenatally or the more than $80 \%$ that arise postnatally, few to none of either set of taste buds formed in $b d n f^{-/-}$mice. Developing taste buds were nerve-dependent whether they were derived from endoderm (vallate) or ectoderm (anterior fungiform and nasopalate) (Zhang et al., 1997; Cooper \& Oakley, 1998; Oakley et al., 1998).

Other methods of disrupting embryonic gustatory innervation, such as the embryonic injection of the neurotoxin beta-bungarotoxin have also demonstrated nerve-dependent taste bud development (MorrisWiman et al., 1999). Postnatal surgical denervation immediately halted the addition of vallate taste buds (Hosley et al., 1987a, b). Further, after a bdnf transgene under control of a nestin promoter caused most 
gustatory neurons to terminate in the BDNF-rich tongue muscle, few vallate taste buds formed (Ringstedt et al., 1999). (Nestin is an intermediate filament protein associated with many developing cells including muscle.) Similarly, Krimm et al., (2001) observed in transgenic mice, whose basal epithelial cells overexpressed BDNF under the control of a cytokeratin 14 promoter, that the fungiform papillae were sparsely innervated and lacked $70 \%$ of their taste buds.

Complementing these loss-of-function demonstrations of the nerve-dependence of taste bud development, a recent gain-of-function study of $b a x^{-1-}$ mice has revealed a marked enhancement of the vallate gustatory organ after the embryonic augmentation of gustatory innervation (Zeng et al., 2000). Bax null mutation spares developing sensory neurons from BAXdependent programmed cell death (Deckworth et al., 1996). Accordingly, when bax null mutation permitted more robust gustatory innervation, the vallate gustatory papilla enlarged, and its taste buds contained more than twice as many taste receptor cells as wildtype controls (Zeng et al., 2000). Just as embryonic lossof-innervation stymies vallate gustatory development, embryonic gain-of-innervation enhances vallate development. There is also preliminary evidence that embryonic hyperinnervation adds more fungiform papillae and taste buds (Krimm et al., 2001).

\section{Fungiform taste bud development and maintenance}

It is well established that some denervated fungiform taste buds can persist in adults, most notably in hamsters, with fewer residual taste buds in rats, and still fewer in gerbils (Whitehead et al., 1985; Ganchrow \& Ganchrow, 1989; Oakley et al., 1993; Whitehead and Kachele, 1994; Nagato et al., 1995). Scattered hamster fungiform taste cells can retain a differentiated phenotype as indicated by immunoreactivity for neural cell adhesion molecule (NCAM), neuron-specific enolase, and ATPase (Barry \& Savoy, 1990; Whitehead et al., 1998). Perhaps denervated fungiform taste buds are sustained by the continued presence of lingual BDNF (Ganchrow et al., 2003; Uchida et al., 2003; cf. Yee et al., 2003).

Null mutation of trkB, or $b d n f$, or $n t 4$ each results in at least a $50 \%$ loss of geniculate neurons followed by compromised development of fungiform papillae and taste buds (Liu et al., 1995; Fritzsch et al., 1997; Nosrat et al., 1997; Zhang et al., 1997; Oakley et al., 1998; Liebl et al., 1997, 1999; Mistretta et al., 1999; Sun \& Oakley, 2002; Agerman et al., 2003). Knockout of both $b d n f$ and $n t 4$ eliminated more than $90 \%$ of geniculate neurons (Liu et al., 1995), corresponding to the 95\% loss of geniculate neurons with the knockout of $\operatorname{trkB}$, whose protein product is the receptor that binds BDNF and NT4 (Fritzsch et al., 1997). In trkB null mutant mice a subset of fungiform papillae developed with little in- nervation (Fritzsch et al., 1997). Fritzsch et al. (1997) did not report on the majority of fungiform taste buds that were missing in $t r k B^{-1-}$ mice-assuredly more than the average of $55 \%$ lost in $b d n f^{-/-}$mice (Mistretta et al., 1999; Sun \& Oakley, 2002; Agerman et al., 2003).

Improvements in organ cultures have made it possible to evaluate the development of nerve-free fungiform papillae under various conditions (Hall et al., 2003; Mistretta et al., 2003). However, notwithstanding the developmental capabilities reported by some and the determined searches put forward by others, no one has reported the development of mammalian taste buds in vitro. It is puzzling that in vitro development has succeeded with fungiform papillae but not with taste buds (Mbiene et al., 1997), given the claim that fungiform papillae and their taste buds can develop in vivo without innervation (Fritzsch et al., 1997). However, what Fritzsch et al. actually examined were selected fungiform taste buds that developed when TrkBdependent innervation was absent but TrkC-expressing innervation was present. If lingual TrkC-expressing innervation sustained by NT3 contributes to taste bud formation, it could resolve the discrepancy between the in vitro and in vivo outcomes. More generally, if the developing gustatory epithelium is responsive to NT3-supported innervation, then the combined loss of BDNF-dependent and NT3-dependent neurons should more severely impair taste bud development. The combination of $b d n f$ and $n t 3$ knockout resulted in a $65 \%$ loss of geniculate neurons and an $85 \%$ loss of the fungiform taste buds vs. the $55 \%$ loss of fungiform taste buds in bdnf knockout mice (Liebl et al., 1997; Nosrat et al., 2005). Surprisingly, $n t 3$ knockout not only eliminated $68 \%$ of trigeminal ganglion neurons, it also eliminated $47 \%$ of the geniculate ganglion neurons (Liebl et al., 1997). Collectively, these observations suggest that NT3 makes a contribution to fungiform taste bud development that may be mediated by both TrkB-expressing neurons and TrkC-expressing neurons. NT4 supported a subset of TrkB-expressing neurons that appear to contribute to fungiform taste bud development (Liebl et al., 1999).

\section{Do mouse lingual taste buds appear by E13?}

In altricial rodents like rats and mice and gerbils most lingual taste buds develop postnatally. Consequently, a wide variety of stains and markers for taste cells including cytokeratin antibodies has given no hint of the presence of taste receptor cells or taste buds in E13E15 mouse tongue or E14-E16 rat tongue-CK8 and other simple cytokeratins are not yet expressed in these tongues, except for the periderm. The periderm is a simple epithelial monolayer that temporarily covers the surface of developing mammalian embryos (from E13 to about E17 in mouse; McGowan \& Coulombre, 1998; Takaishi et al., 1998; from week 8-12 in human fungiform papillae: Witt \& Reutter, 1996). Peridermal 
cells express simple cytokeratins including CK8 (Lane et al., 1985). The lingual periderm sloughs off in late embryogenesis, leaving the mouse tongue nearly free of CK8-positive cells a few days before birth. CK8 staining within the mouse tongue is first evident in a few taste cells and salivary duct cells about E17 (Zeng et al., 2000; Sun \& Oakley, 2002; Fan et al., 2004). Surprisingly, Mbiene and Roberts (2003) reported that the E13 mouse lingual epithelium had widespread CK8 staining in which "embryonic taste buds" were resolved. It is unclear how CK8 staining was achieved with a Troma-I dilution of 1:2000, since the experience of others using the same source of the CK8 specific antibody has been that a dilution of 1:80 fails to stain any lingual epithelial cells at E13--E15 and a dilution of 1:200 is too weak to stain taste buds at any age.

\section{Taste buds fail to develop in $\mathrm{bdnf}^{-/-}$mice in the absence of innervation}

The absence of taste buds in $b d n f^{-/-}$mice may be explained by three alternative mechanisms: One alternative is that the developmental absence of BDNF in the gustatory epithelium caused the shortfall of taste buds. A pair of studies have tested this possibility by increasing the availability of BDNF in non-gustatory lingual tissue without reducing BDNF levels in gustatory papillae. After ectopic expression of BDNF, gustatory neurons terminated in the deep muscles of the tongue (Ringstead et al., 1999) or terminated in the non-gustatory epithelium including the filiform papillae (Krimm et al., 2001). In both experiments the misdirection of gustatory axons into non-gustatory tissue resulted in sparsely innervated gustatory papillae with few taste buds, even though the BDNF levels were not reduced in the gustatory epithelium.

The gustatory papillae in $b d n f^{-1-}$ mice have three major deficiencies, clearly visible in vallate taste organ development. In addition to sparse innervation and few taste buds the vallate papilla is morphologically distorted. Perhaps the area of the gustatory epithelium was so diminished that it was too small to accommodate more taste buds. This second alternative has been quantitatively evaluated in $b d n f^{-/-}$mice. The shortfall of taste buds was $76 \%$ at P7 and $90 \%$ at P12 when the area of the vallate gustatory epithelium was reduced by $34 \%$ and 56\%, respectively (Oakley et al., 1998). Thus, even though most taste buds failed to form, both by visual and quantitative assessment, the vallate trench walls in $b d n f^{-/-}$mice had ample room for additional taste buds. Similarly, in the nasopalatine papilla in $b d n f^{-/-}$mice, where sparse innervation was associated with $70 \%$ fewer taste buds, papilla morphology was minimally altered (Cooper \& Oakley, 1998). Moreover, neonatal denervation of the rat vallate papilla prevented the formation of hundreds of taste buds for which there was ample room in vallate trench walls that were nearly empty (Hosley et al., 1987a, b). In addition, there is a marked increase in the size or number of taste buds after experimentally increased innervation: during mouse embryogenesis (Zeng et al., 2000), during the P0-P30 day neonatal period in rats (Hosley et al., 1987b), or during adulthood in gerbils (Riddle et al., 1987)-increases that in each instance are associated with negligible changes in papilla morphology. We conclude that neither the absence of BDNF nor the distortion of gustatory papillae can account for the shortfall of taste buds in $b d n f^{-/-}$mice. The obvious remaining third alternative is that taste bud development has a primary dependence upon gustatory innervation. To propose that denervation may impair the cellular competence of the gustatory epithelium is to embark on a consideration of how it is that nerves contribute to taste bud development.

The nerve-dependency of lingual gustatory papillae and taste buds begins to subside with postnatal aging in rodents (Hosley et al., 1987a,b; Ganchrow \& Ganchrow, 1989; Oakley et al., 1991, 1993b; Nagato et al., 1995). Mammalian muscle spindles, and Pacinian corpuscles also seem to follow a similar progression-an initial requirement for neural induction followed by a postnatal decline in nerve-dependence (reviewed in Zelena, 1994). Thus, although it was proposed that mammalian taste buds might be initiated without neural influence and thereafter become increasingly dependent upon innervation with age (Northcutt and Barlow, 1998), the data require a different interpretation.

\section{Molecular specification of gustatory epithelia}

The multiple demonstrations of the indispensability of innervation for mammalian taste bud development form a natural bridge to investigations about the state of the gustatory epithelium when taste axons arrive. The vast majority of mammalian taste buds will arise only if they are induced by chemosensory fibers from an epithelium competent for gustation. Numerous molecules have a more or less specific expression in the gustatory portions of the tongue (Ganchrow, 2000). Which of such molecules help to localize lingual papillae and prime the epithelial patch to respond to approaching gustatory innervation? Candidate gene products well-positioned to influence the placement of taste papillae, and perhaps the responsiveness of their cells to innervation, include bone morphogenetic proteins 2 and 4, distalless 3, sonic hedgehog, patched, Gli1, fibroblast growth factor 8, and the ErbB receptor family (Bitgood \& McMahon, 1995; Morrasso et al., 1995; Hall et al., 1999; Jung et al., 1999; McLaughlin, 2000; Miura et al., 2001). Sonic hedgehog (shh) may negatively regulate the development of fungiform papilla and their spatial distribution in conjunction with other factors (Hall et al., 2003; Mistretta et al., 2003; Fig. 4). Proposed flow charts must accommodate regional differences in control mechanisms. For 


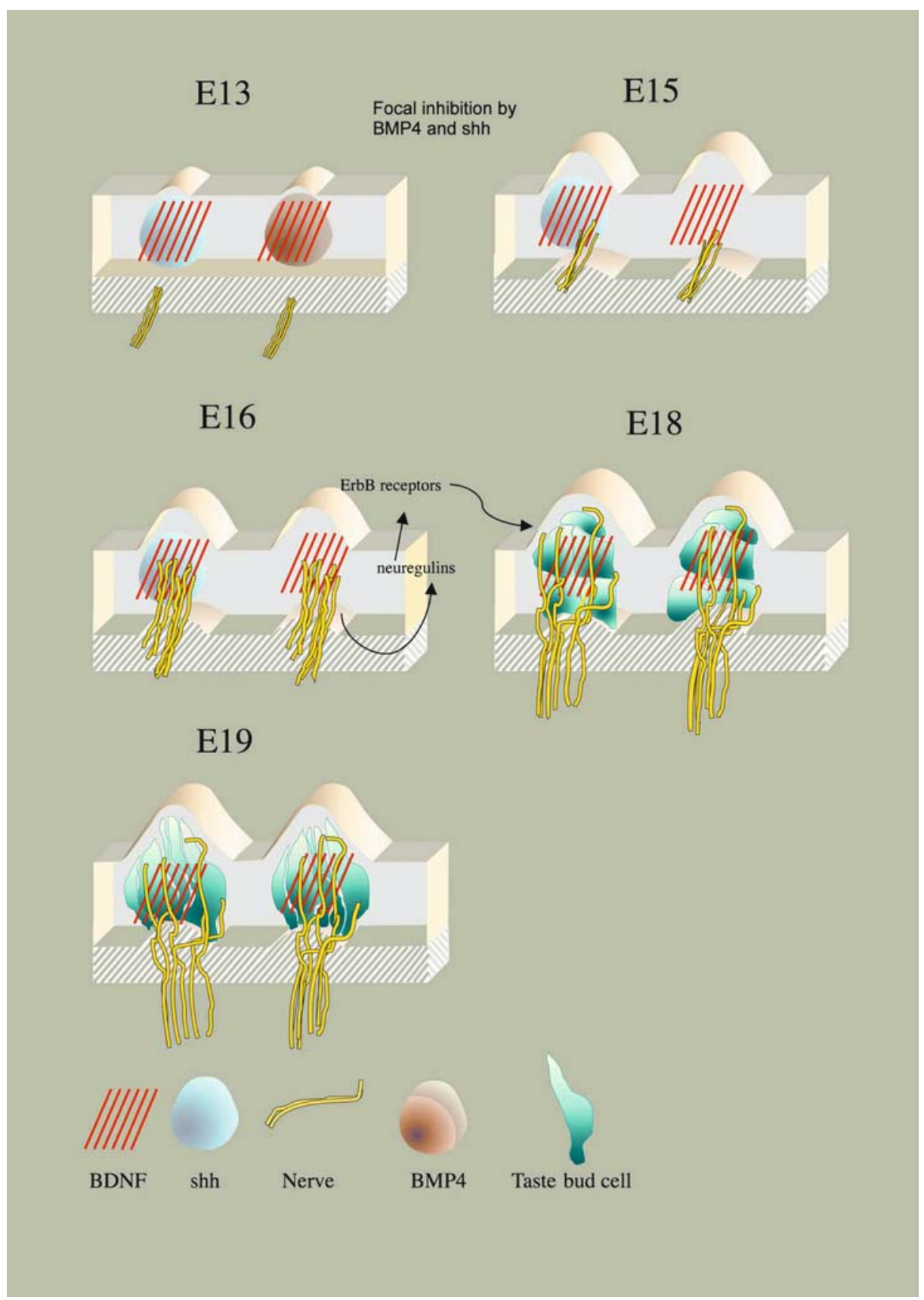

Fig. 4. Schematic, paradigmatic outline of the sequence of events involved in the development of mouse taste buds. Fungiform papillae develop from embryonic day 13 to E19/birth. Bone morphogenetic protein 4 (BMP4) and sonic hedgehog (Shh) appear to regulate the development of nascent fungiform papillae. Gustatory target cells express BDNF (oblique red lines) that will sustain gustatory innervation. Neuronal-epithelial interactions prompt taste bud formation and further papilla development. Activation of tissue ErbB receptors by axonal neuregulins may contribute to taste organ development and maintenance.

example, the anterior taste buds on the roof of the mouth and on the tongue require EGFR during development, in contrast to the posterior taste buds (Sun \& Oakley, 2002).

\section{What are the axonal signals that sustain taste papilla growth and evoke taste bud development?}

The tips of growing axons arrive in the mouse tongue over a span of several days. It is unknown how far the axon must penetrate into the mesenchyme to influence the overlying epithelium-some neurotrophic influences on gustatory epithelia may occur before more intimate axonal-epithelial contact. Thus, rather than attempting to identify neurally regulated molecules by pinpointing the instant of axonal influence, a better approach may be to screen sparsely innervated induced mutant mouse tongues for the up- or downregulation of messages or molecules that are normally 
associated with intact gustatory innervation. Since taste cells sometimes support action potentials, release neurotransmitter and perhaps receive neurotransmitters, and express neuronal markers like NCAM, neuronspecific enolase, Mash1, and NeuroD, one may consider taste buds to be clusters of axonless neurons (Roper, 1983; Bigiani \& Roper, 1991; Montavon \& Lindstrand, 1991; Takeda et al., 1992; Seta et al., 1999; Ganchrow, 2000; Miura et al., 2001; Kusakabe et al., 2002). In addition, surgical disruption of the glossopharyngeal nerve in mice caused an immediate decrease of shh expression in vallate basal taste bud cells, which re-appeared after re-innervation (Miura et al., 2004). It is likely that axons supply trophic agents to taste receptor cells because even though the chronic impairment of gustatory axonal transport spared axonal impulse propagation mechanisms, it nonetheless caused a loss of taste responses followed by a loss of taste buds (Sloan et al., 1983). The release of neuregulins by gustatory axons may signal gustatory stem cells or their daughters to express neurogenic genes. Neuregulins and other EGF family ligands signal through ErbB receptors, known to be present in mouse embryonic gustatory epithelia (McLaughlin, 2000). Protein tyrosine kinases such as IGF 1 receptor (Suzuki et al., 2005), EGFR and perhaps other ErbB receptors may be vital to taste bud development (Sun \& Oakley, 2002). During taste receptor cell differentiation, differential gene expression generates useful markers, including Mash 1, NeuroD, ErbB receptors, CD44, various lectin binding sites, and simple cytokeratins. Gustatory NeuroD first appears on postnatal day 3 (Suzuki et al., 2002). The proneural gene Mash1 is not only expressed during taste papilla development but is also expressed in a nervedependent manner in adult rat gustatory basal cells (Seta et al., 1999), consistent with a gustatory axonal contribution to the development and the renewal of taste cells. Taste cell-specific markers like CK20 and CD44 (in mammals) or calretinin (in amphibians and fish) appear early, but it has been difficult to identify markers that precede innervation (Witt \& Kasper, 1998; Northcutt, 2005). The BDNF expressed before innervation probably reflects its traditional role, shared by all neurotrophins, of validating appropriate sensory neurons whose axons navigate into their peripheral target.

\section{Stable gustatory coded messages in the presence of taste receptor cell turnover}

The fidelity and stability of sensory coding requires the continued maintenance of peripheral sense organs. Not only are lingual somatosensory and gustatory organs destined to confront environmental stresses like extremes of $\mathrm{pH}$ and temperature, they must also cope with the special challenges posed by the death (Zeng \& Oakley, 1999) and the replacement of receptor cells
(Beidler \& Smallman, 1965; Takeda, 1979; Farbman, 1980).

Receptor cell turnover puts taste axons at risk of frequent changes in the intensity and quality of their coded gustatory messages. Axonal connections with receptor cells must be regulated since two branches of a chorda tympani single fiber innervate taste receptor cells with similar taste response profiles (Oakley, 1975). The first recordings from cross-regenerated chorda tympani nerves and glossopharyngeal nerves revealed tissue-specific rather than nerve-specific taste responses (Oakley, 1967). These results and later studies of regenerating single chorda tympani taste axons (Cheal et al., 1977) suggest that each type of taste axon matches with one or more receptor cells having a corresponding taste sensitivity. Recent electrophysiological and behavior studies of reinnervation by two classes of salt fibers provide further support for axon-receptor cell matching (Ninomiya, 1998; Yasumatsu et al., 2003). Regenerating amiloride-insensitive salt fibers regained responsiveness before amiloride-sensitive fibers; salt fibers did not spend transitional periods with mixed or attenuated sensitivity. System-wide fluctuations in signal intensity owing to the normal remodeling of neural connections may be minimized by out-of-phase variations in signal intensity across taste buds.

\section{What the assembled facts imply}

Single and double null mutations of NT3, BDNF, and NT4 cause partial losses of geniculate ganglion cells (Table 1). A simple model of neurotrophin spatial distribution in the fungiform papillae helps to explain the differences in neurotrophin support of geniculate neurons (Fig. 5). Consider each fungiform papilla as a large cylinder composed of five concentric cylinders. As suggested by developmental observations (Nosrat et al., 1996), the perimeter of the fungiform papilla expresses NT3 that supports trigeminal somatosensory neurons. This region surrounds a cylinder of NT3-expressing tissue that supports $10 \%$ of the geniculate neurons. NT3 and BDNF in the next cylinder are both required for the support of $40 \%$ of the neurons, BDNF and NT4 in the

Table 1. Compilation of geniculate ganglion cell losses in various neurotrophin mutant models.

\begin{tabular}{lll}
\hline Neurotrophin KO & Neurons lost (\%) & Reference \\
\hline NT3 & 47 & Liebl et al., 1997 \\
BDNF & 50 & several papers \\
NT4 & 50 & Liu et al., 1995 \\
NT3/-BDNF & 65 & Liebl et al., 1997 \\
NT4/-BDNF & 90 & Liu et al., 1995 \\
TrKB & 95 & Fritzsch et al., 1997 \\
NT4/-NT3 & 100 & Predicted loss \\
& & (no data on this) \\
\hline
\end{tabular}




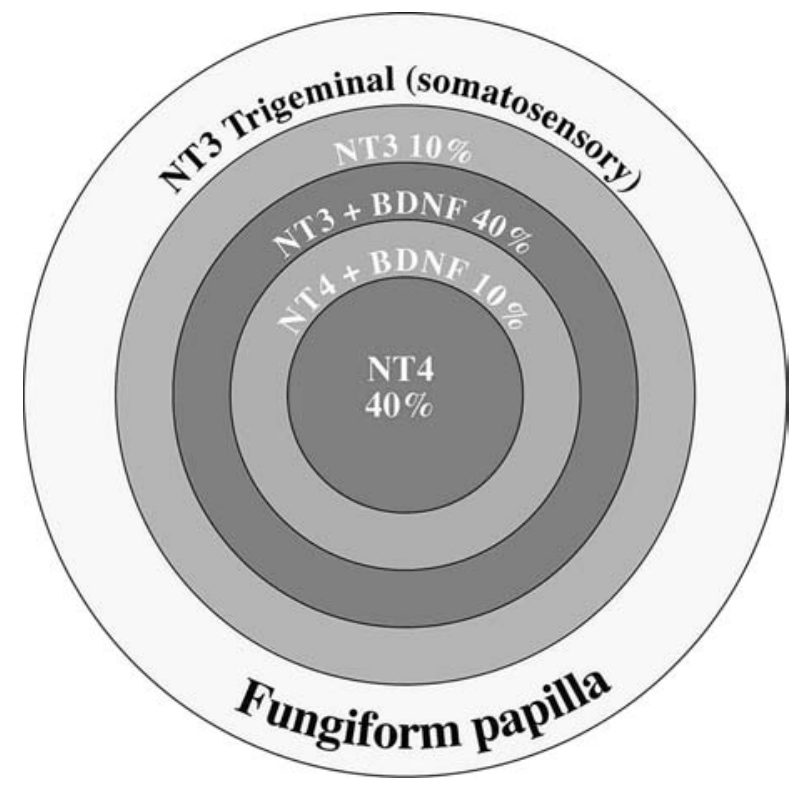

Fig. 5. A schematic model of the mouse fungiform papilla shows a hypothetical distribution of neurotrophins that accounts within $\pm 5 \%$ for the loss of geniculate ganglion cells reported in single and double knockout studies of neurotrophin genes (see Table 1). In this model BDNF expression partially overlaps the spatial expression patterns of NT3 and NT4, as indicated by concentric cylinders in a top view of a fungiform papilla. In the outermost ring NT3 expression supports numerous trigeminal somatosensory neurons, but no geniculate neurons. The fraction of geniculate neurons that is supported by the neurotrophin(s) within each cylindrical ring is given as a percentage of all geniculate neurons.

next cylinder together support $10 \%$ of the neurons, and NT4 in the core cylinder supports $40 \%$ of the geniculate neurons. The model accounts for the knockout results in Table 1 within $\pm 5 \%$, assuming all fungiform papillae have similar patterns of innervation and neurotrophin expression. Further, the model makes two explicit predictions: future studies will show NT4 is localized to the core of fungiform papillae, and few if any geniculate neurons will survive NT3/NT4 double knockout.

The decade old conjecture that mammalian taste buds could develop without innervation (Barlow \& Northcutt, 1996) was in conflict with the relevant empirical data from the outset and has not been supported by the results of eleven recent additional experimental investigations in mammals. Even though it has been substantiated, the neural induction of taste buds is but one link in a chain of developmental events. Rather than the axoplasm of gustatory neurons supplying a rich flow of diverse regulatory molecules, it is more likely that gustatory axons have a limited trophic engagement with epithelial cells already primed to unleash an intracellular regulatory cascade. We are still remarkably ignorant about the molecular environment, such as the signals that direct nerves to specific ectoder- mal regions in early development, the state of molecular differentiation, and the kinds of gustatory cells present before and during innervation. Perhaps relatively minor differences in the tissue milieu or cellular responsiveness account for the greater autonomy of urodele taste buds. Even after the differentiation of mammalian taste receptor cells, continuous innervation is required to insure the transmission of sensory signals, to prompt or permit new cells to replace the old, and perhaps to sustain differentiated taste cells for their normal life span. We look forward to data-fresh, hard-won experimental data-that disentangles the molecular mechanisms controlling gustatory developmental events before, during, and after innervation.

\section{Acknowledgments}

We thank our respective supporting agencies, the US National Institutes of Health and the National Science Foundation, and The University of Michigan Department of Cellular, Molecular and Developmental Biology. We also thank our colleagues, especially Dr. C. Nosrat, for their many contributions and suggestions, and Mrs I.Beck for help with artwork.

\section{References}

AGERMAN, K., HERLING-LEFFLER, J., BLANCHARD, M. P., SCARFONE, E., CANLON, B., NOSRAT, C. \& ERNFORS, P. (2003) BDNF gene replacement reveals multiple mechanisms for establishing neurotrophin specificity during sensory nervous system development. Development 130, 1479-1491.

BARRY, M. A. \& SAVOY, L. D. (1993). Persistence and calcium-dependent ATPase staining of denervated fungiform taste buds in the hamster. Archives of Oral Biology 38, 5-15.

BARLOW, L. A. (1999) A taste for development. Neuron 22, 209-212.

BARLOW, L.A., CHIEN. C.-B. \& NORTHCUTT, R. G. (1996) Embryonic taste buds develop in the absence of innervation. Development 122, 1103-1111.

BARLOW, L. A. \& NORTHCUTT, R. G. (1997) Taste buds develop autonomously from endoderm without induction by cephalic neural crest or paraxial mesoderm. Development 124, 949-957.

BEIDLER, L. M. \& SMALLMAN, R. L. (1965) Renewal of cells within taste buds. Journal of Cell Biology 27, 263-272.

BIGIANI, A., GHIARONI, V. \& FIENI, F. (2003) Channels as taste receptors in vertebrates. Progress in Biophysics $\mathcal{E}$ Molecular Biology 83, 193-225.

BIGIANI, A. R. \& ROPER, S. D. (1991) Mediation of responses to calcium in taste cells by modulation of a potassium conductance. Science 252, 126-128.

BITGOOD, M. J. \& MCMAHON, A. P. (1995). Hedgehog and bmp genes are coexpressed at many diverse sites of cellcell interaction in the mouse embryo. Developmental Biology 172, 126-138. 
BROCKES, J. P. (1997) Amphibian limb regeneration: Rebuilding a complex structure. Science 276, 81-87.

CHEAL, M., DICKEY, W. P., JONES, L. B. \& OAKLEY, B. (1977) Taste fiber responses during reinnervation of fungiform papillae. The Journal of Comparative Neurology 172, 627-646.

COOPER, D. \& OAKLEY, B. (1998) Functional redundancy and gustatory development in $b d n f$ null mutant mice. Developmental Brain Research 105, 79-84.

DECKWERTH, T. L., ELLIOTT, L. L., KNUDSON, C. M., JOHNSON, E. M., SNIDER, W. D. \& KORSMEYER, S. J. (1996) Bax is required for neuronal death after trophic factor deprivation and during development. Neuron 17, 401-411.

DINGER B., FIDONE, S. J. \& STENSAAS L. J. (1985) Regeneration of taste buds by nongustatory nerve fibers. Experimental Neurology 89, 189-203.

EL-SHARABY, A., UEDA, K. \& WAKISADA, S. (2004) Immumohistochemical distribution of growth-associated protein 43 (GAP-43) in developing rat nasoincisor papilla. Anatomical Record, 277(A), 370-83.

ERNFORS, P., LEE, K.-F., KUCERA, J. \& JAENISCH, R. (1994) Lack of neurotrophin-3 leads to deficiencies in the peripheral nervous system and loss of limb proprioception. Cell 77, 503-512.

FAN, L., GIRNIUS, S. \& OAKLEY, B. (2004) Support of trigeminal sensory neurons by nonneuronal p75 neurotrophin receptors. Developmental Brain Research 150, 23-39.

FARBMAN, A. I. (1980) Renewal of taste bud cells in rat circumvallate papillae. Cell and Tissue Kinetics 13, 349-357.

FARBMAN, A. I. (2003) Neurotrophins and taste buds. The Journal of Comparative Neurology 459, 9-14.

FARBMAN, A. I. \& MBIENE, J. P. (1991). Early development and innervation of taste bud-bearing papillae on the rat tongue. The Journal of Comparative Neurology 304, 172-186.

FARIÑAS, I., JONES, K. R., BACKUS, C., WANG, X. \& REICHARDT, L. F. (1994) Severe sensory and sympathetic deficits in mice lacking neurotrophin-3. Nature 369, 658-661.

FRITZSCH, B., SARAL, P. A., BARBACID, M. \& SILOSSANTIAGO, I. (1997) Mice with a targeted disruption of the neurotrophin receptor trkB lose their gustatory ganglion cells early but do develop taste buds. International Journal of Developmental Neuroscience. 15, 563576.

GANCHROW, J. R. (2000) Taste cell function: Structural and biochemical implications. Physiology and Behavior 69, 29-40.

GANCHROW, J. R. \& GANCHROW, D. (1989) Long-term effects of gustatory neurectomy on fungiform papillae in the young rat. Anatomical Record 225, 224-231.

GANCHROW, D. GANCHROW, J. R., VERDINALCAZAR, M. \& WHITEHEAD, M. C. (2003) Brain-derived neurotrophic factor-, neurotrophin-3-, and tryrosine kinase receptor-like immunoreactivity in lingual taste bud fields of mature hamster after sensory denervation. The Journal of Comparative Neurology 455, 25-39.

GILbERTSON, T. A. \& BOUGHTER, J. D. Jr. (2003) Taste transduction: Appetizing times in gustation. Neuroreport
14, 905-911.

HALL, J. M., BELL, M. L. \& FINGER, T. E. (2003) Disruption of sonic hedgehog signaling alters growth and patterning of lingual taste papillae. Developmental Biology 255, 263-77.

HALL, J. M., HOOPER, J. E. \& FINGER, T. E. (1999). Expression of sonic hedgehog patched, and Gli1 in developing taste papillae of the mouse. The Journal of Comparative Neurology 406, 143-155.

HÅRD AF SEGERSTAD， C., HELLEKANT, G. \& FARBMAN, A.I. (1989) Changes in number and morphology of fungiform taste buds in rat after transection of the chorda tympani or chorda-lingual nerve. Chemical Senses 14, 335-348.

HOSLEY, M. A., HUGHES, S. E. \& OAKLEY, B. (1987a) Neural induction of taste buds. The Journal of Comparative Neurology 260, 224-232.

HOSLEY, M. A., HUGHES, S. E., MORTON, L. L. \& OAKLEY, B. (1987b) A sensitive period for the neural induction of taste buds. Journal of Neuroscience 7, 2075-2080.

HOSLEY, M.A. \& OAKLEY, B. (1987) Postnatal development of the vallate papilla and taste buds in rats. Anatomical Record 218, 216-222.

JUNG, H. S., OROPEZA, V. \& THESLEFF, I. (1999) Shh, Bmp-2, Bmp-4 and Fgf- 8 are associated with initiation and patterning of mouse tongue papillae. Mechanisms of Development 81, 179-182.

KIM, U.-K., BRESLIN, P. A. S., REED, D. \& DRAYNA, D. (2004) Genetics of human taste perception. Journal of Dental Research 83, 448-453.

KIM, J. Y., MOCHIZUKI, T., AKITA, K. \& JUNG, H. S. (2003) Morphological evidence of the importance of epithelial tissue during mouse tongue development. Experimental Cell Research 290, 217-226.

KNAPP, L., LAWTON, A., OAKLEY, B., WONG, L. \& ZHANG, C. (1995) Keratins as markers of differentiated taste cells. Differentiation 58, 341-349.

KRIMM, R. F., MILLER, K. K., KITZMAN, P. H., DAVIS, B. M. \& ALBERS, K. M. (2001) Epithelial overexpression of BDNF or NT4 disrupts targeting of taste neurons that innervate the anterior tongue. Developmental Biology 232, 508-21.

KUSAKABE, Y., MIURA, H., HASHIMOTO, R., SUGIYAMA, C. NONOMIYA, Y. \& HINO, A. (2002) The neural differentiation gene mash-1 has a distinct pattern of expression from the taste receptionrelated genes gustducin and T1R2 in the taste buds. Chemical Senses 27, 445-51.

LANE, E. B., BARTEK, J., PURKIS, P. E. \& LEIGH, I. M. (1985) Keratin antigens in differentiating skin. Annuals of the New York Academy of Sciences 455, 241-258.

LEE, K. F., KI, E., HUMBER, L. J., LANDIS, S. C., SHARPE, A. H., CHAO, M. V. \& JAENISCH, R. (1992) Targeted mutation of the gene encoding the low affinity NGF receptor p75 leads to deficits in the peripheral sensory nervous system, Cell 69, 737-749.

LIEBL, D. H., MBIENE, J. P. \& PARADA, L. F. (1999) NT4/5 mutant mice have deficiency in gustatory papillae and taste bud formation. Developmental Biology 213, 378-389.

LIEBL, D.H., TESSAROLlO, L., PALKO, M. E. \& PARADA, L. F. (1997) Absence of sensory neurons 
before target innervation in brain-derived neurotrophic factor-, neurotrophin 3-, and TrkC-deficient embryonic mice. The Journal of Neuroscience 17, 9113-9121.

LIU, X., ERNFORS, P., WU, H. \& JAENISCH, R. (1995). Sensory but not motor neuron deficits in mice lacking NT4 and BDNF. Nature 375, 238-241.

MBIENE, J. P., MACCALLUM, D. \& MISTRETTA, C. M. (1997) Organ cultures of embryonic rat tongue support tongue and gustatory papillae morphogenesis in vitro without intact sensory ganglia. The Journal of Comparative Neurology 377, 324-340.

MBIENE, J.-P. \& ROBERTS, J. D. (2003) Distribution of keratin 8-containing cell clusters in mouse embryonic tongue: Evidence for a prepattern for taste bud development. The Journal of Comparative Neurology 457, 111-22.

MCGOWAN, K. M. \& COULOMBRE, P. A. Onset of keratin 17 expression coincides wit the definition of major epithelial cell lineages during skin development. The Journal of Cell Biology 143, 469-486.

MCLAUGHLIN, S. K. (2000). Erb and c-Kit receptors have distinctive patterns of expression in adult and developing taste papillae and taste buds. The Journal of Neuroscience 20, 5679-5688.

MISTRETTA, C. M., GOOSENS, K. A., FARIÑAS, I. \& REICHARDT, L. F. (1999) Alterations in size, number and morphology of gustatory papillae and taste buds in BDNF null mutant mice demonstrate neural dependence of developing taste organs. The Journal of Comparative Neurology 409, 13-24.

MistretTA, C. M., LIU, H.-X., GAFFIELD, W. \& MACCALLUM, D. K. (2003) Cyclopamin and jervine in embryonic rat tongue cultures demonstrate a role for Shh signaling in taste papilla development and patterning: Fungiform papillae double in number and form in novel locations in dorsal lingual epithelium. Developmental Biology 254, 1-18.

MIURA, H., KATO, H., KUSAKABE, Y., TAGAMI, M., MIURA-OHNUMA, J., NINOMIYA, Y. \& HINO, A. (2004). A Strong Nerve Dependence of Sonic hedgehog Expression in Basal Cells in Mouse Taste Bud and an Autonomous Transcriptional Control of Genes in Differentiated Taste Cells. Chemical Senses 29, 82331.

MIURA, H., KUSAKABE, Y., SUGIYAMA, C., KAWAMATSU, M., NINOMIYA, Y., MOTOYAMA, J. \& HINO, A. (2001). Shh and ptc are associated with taste bud maintenance in the adult mouse. Mechanisms of Development 106, 143-45.

MONTAVON, P., HELLEKANT, G. \& FARBMAN, A. (1996) Immunohistochemical, electrophysiological, and electron microscopical study of rat fungiform taste buds after regeneration of chorda tympani through the nongustatory lingual nerve. The Journal of Comparative. Neurology. 367, 491-502.

MONTAVON, P. \& LINDSTRAND, K. (1991) Immunocytochemical localization of neuron-specific enolase and calcitonin gene-related peptide in rat taste papillae. Regulatory Peptides 36, 219-233.

MONTMAYEUR, J. P. \& MATSUNAMI, H. (2002) Receptors for bitter and sweet taste. Current Opinion in Neurobiology 12, 366-371.

MORASSO, J. I., MAHON, K. A. \& SARGENT, T. D.
(1995). A Xenopus distal-less gene in transgenic mice: Conserved regulation in distal limb epidermis and other sites of epithelial-mesenchymal interaction. Proceedings of the National Academy of Science USA 92, 3968-3972.

MORRIS-WIMAN, J., BASCO, E. \& DU, Y. (1999). The effects of B-Bungarotoxin on the morphogenesis of taste papillae and taste buds in the mouse. Chemical Senses 24, 7-17.

NAGATO, T., MATSUMOTO, K., TANIOKA, H., KODAMA, J. \& TOH, H. (1995). Effect of denervation on morphogenesis of the rat fungiform papilla. Acta Anatomica 153, 301-309.

NINOMIYA, Y. (1998) Reinnervation of cross-regenerated gustatory nerve fibers into amiloride-sensitive and amiloride-insenstive taste receptor cells. Proceedings of the National Academy of Science USA 95, 5347-5350.

NORTHCUTT, R. G. (2004) Taste buds: Development and evolution. Brain Behavior and Evolution 64, 198-206.

NORTHCUTT, R. G. \& BARLOW, L. A. (1998) Amphibians provide new insights into taste-bud development. Trends in Neuroscience 21, 38-43.

NOSRAT, I. V., AGERMAN, K., ERNFORS, P. \& NOSRAT, C. A. (2005) Combinatorial gustatory and somatosensory deficits in neurotrophin double knockout mice. Journal of Neurocytology, XXX

NOSRAT, C. A., BLOMLOF, J., ELSHAMY, W. M., ERNFORS, P. \& OLSON, L. (1997) Lingual deficits in BDNF and NT3 mutant mice leading to gustatory and somatosensory disturbances, respectively. Development 124, 1333-1342.

NOSRAT, C. A., EBENDAL, L. \& OLSON, L. (1996). Differential expression of brain-derived neurotrophic factor and neurotrophin $3 \mathrm{mRNA}$ in lingual papillae and taste buds indicates roles of gustatory and somatosensory innervation. The Journal of Comparative Neurology 376, 587-602.

NOSRAT, I. V., LINDSKOG, S., SEIGER A. \& NOSRAT, C. A. (2000) Lingual BDNF and NT-3 mRNA expression patterns and their relation to innervation in the human tongue: Similarities and differences compared with rodents. The Journal of Comparative Neurology 417, 133-152.

NOSRAT, C. A., MACCALLUM, D. K. \& MISTRETTA, C. M. (2001) Distinctive spatiotemporal expression patterns for neurotrophins develop in gustatory papillae and lingual tissues in embryonic tongue organ cultures. Cell and Tissue Research 303, 35-45.

NOSRAT, C. A. \& OLSON, L. (1995) Brain-derived neurotrophic factor mRNA is expressed in the developing taste bud-bearing tongue papillae of rat. The Journal of Comparative Neurology 360, 698-704.

OAKLEY, B. (1967) Altered temperature and taste responses from cross-regenerated sensory nerves in the rat's tongue. Journal of Physiology 188, 353-371.

OAKLEY, B. (1975) Receptive fields of cat taste fibers. Chemical Senses and Flavor 1, 431-442.

OAKLEY, B. (1993a) Control mechanisms in taste bud development. In: Mechanisms of Taste Transduction (S.A. Simon and S.D. Roper, eds) CRC Press, Boca Raton, FL., pp. 105-125.

OAKLEY, B. (1993b) The gustatory competence of the lingual epithelium requires neonatal innervation. Developmental Brain Research 72, 259-264. 
OAKLEY, B. (1998) Taste neurons have multiple inductive roles in mammalian gustatory development. Annals of the New York Academy of Sciences 855, 50-57.

OAKLEY, B. \& BENJAMIN, R. M. (1966) Neural mechanisms of taste. Physiological Reviews 46, 173-211.

OAKLEY, B., BRANDEMIHL, A., COOPER, D., LAU, D., LAWTON, A. \&ZHANG, C. (1998) The morphogenesis of mouse vallate gustatory epithelium and taste buds requires BDNF-dependent taste neurons. Developmental Brain Research 105, 85-96.

OAKLEY, B, LABELLE, D. E., RILEY, R. A., WILSON, K. \& LI, L.W. (1991) The rate and locus of development of rat vallate taste buds. Developmental Brain Research 58, 215-221.

OAKLEY, B., LAWTON, A., RIDDLE, D. R. \& WU, L. H. (1993) Morphometric and immunocytochemical assessment of fungiform taste buds after interruption of the chorda-lingual nerve. Microscopy and Research Techniques 26, 187-195.

OAKLEY, B., WU, L. H., LAWTON, A. \& DESIBOUR, C. L. (1990) Neural control of ectopic filiform spines in adult tongue. Neuroscience 36, 831-838.

REUTTER, K. \& WITT, M. (1993) Morphology of vertebrate taste organs and their nerve supply, In: Mechanisms of Taste Transduction (SIMON, S.A. \& ROPER, S.D., eds.) CRC Press, Boca Raton, FL., pp. 29-81.

RINGSTEDT, T., IBANEZ, C. F. \& NOSRAT, C. A. (1999) Role of brain-derived neurotrophic factor in target invasion in the gustatory system. The Journal of Neuroscience 19, 3507-3518.

RIDDLE, D. R., HUGHES, S. E. \& OAKLEY, B. (1987) Some effects upon fungiform and foliate taste buds of condensing the innervation by the chorda tympani nerve. Chemical Senses, 12, 691.

ROPER, S. (1983) Regenerative impulses in taste cells. Science, 220, 1311-1312

SAWAF, M. H., OUHAYOUN, J. P. \& FOREST, N. (1991) Cytokeratin profiles in oral epithelia: A review and a new classification. Journal of Biologie Buccale 19, 187-198.

SETA, Y., TOYONO, T., TAKEDA, S. \& TOYOSHIMA, K. (1999) Expression of Mash1 in basal cells of rat circumvallate taste buds is dependent upon gustatory innervation. Federation of Experimental Biology Societies Letters 444, 43-46.

SHULER, M. G., KRIMM, R. F. \& HILL, D. L. (2004) Neuron/target plasticity in the peripheral gustatory system. The Journal of Comparative Neurology 472, 183-92.

SLOAN, H. E., HUGHES, S. E. \& OAKLEY, B. (1983) Chronic impairment of axonal transport eliminates taste responses and taste buds. The Journal of Neuroscience 3, 117-123.

STONE, L. S. (1933) Independence of taste organs with respect to their nerve fibers demonstrated in living salamanders. Proceedings of the Society for Experimental Biology and Medicine 30, 1256-1257.

STONE, L. S. (1940) The origin and development of taste organs in salamanders observed in the living condition. Journal of Experimental Zoology 83, 481506.

SUN, H. \& OAKLEY, B. (2002) Development of anterior gustatory epithelial in the palate and tongue requires epidermal growth factor receptor, Developmental Biology 242,
$31-43$.

SUZUKI, Y., TAKEDA, M. \& OBARA, N. (2002) Expression of Neuro D in the mouse taste buds. Cell and Tissue Research 307, 423-428.

TAKAISHI, M., TAKATA, Y., KUROKI, T. \& HUH, N. (1998). Isolation and characterization of a putative keratin-associated protein gene expressed in embryonic skin of mice. Journal of Investigative Dermatology 111, 128-32.

TAKEDA, M. (1979) Tritiated thymidine autoradiographic study of taste buds in the mouse. Acta Anatomica Nippon 54, 230-231.

TAKEDA, M., SUZUKI, Y. , OBARA, N. \& NAGAI, Y. (1992) Neural Cell adhesion molecule of taste buds. Journal of Electron Microscopy 41, 375-80.

TOYOSHIMA, K., SETA, Y., TOYONO, T. \& TAKEDA, S. (1999) Merkel cells are responsible for the initiation of taste organ morphogenesis in the frog. Journal of Comparative Neurology 406, 129-40.

TYLER, M., DANILOV, Y. \& BACH-Y-RITA, P. (2003) Closing an open-loop control system: Vestibular substitution through the tongue. Journal of Integrative Neuroscience 2, 159-64.

UCHIDA, N., KANAZAWA, M., SUZUKI, Y.\& TAKEDA, M. (2003) Expression of BDNF and TrkB in mouse taste buds after denervation and in circumvallate papillae during development. Archives of Histology \& Cytology 66, $17-25$.

VINTSCHGAU VON, M.V. \& HÖNIGSCHMIED, J. (1877) Nervus Glossopharyngeus und Schmeckbecher Archiv der Gesamten Physiologie 14, 443-448.

WHITEHEAD, M. C., FRANK, M. E., HETTINGER, T. P., HOU, L. T. \& NAH, H. D. (1985). Persistence of taste buds in denervated fungiform papillae. Brain Research 405, 192-195.

WHITEHEAD, M. C., GANCHROW, J. P., GANCHROW, D. \& YAO, B. (1998) Neural cell adhesion molecule, neuron-specific enolase and calcitonin gene-related peptide immunoreactivity in hamster taste buds after chorda tympani/lingual nerve denervation. Neuroscience 83, 843-56.

WHITEHEAD, M. C. \& KACHELE, D. L. (1994) Development of fungiform papillae, taste buds, and their innervation in the hamster. The Journal of Comparative Neurology 340, 515-530.

WITT, M. \& KASPER, M. (1998) Immunohistochemical distribution of CD44 and some of its isoforms during human taste bud development. Histochemistry and Cell Biology 110, 95-103.

WITT, M. \& KASPER, M. (1999) Distribution of cytokeratin filaments and vimentin in developing human taste buds Anatomy and Embryology 199, 291-99.

WITT, M. \& REUTTER, K. (1996) Embryonic and early fetal development of human taste buds: A transmission electron microscopical study Anatomical Record 246, 50723.

WITT, M. \& REUTTER, K. (1998) Innervation of developing human taste buds. An immunohistochemical study. Histochemistry and Cell Biology 109, 281-91.

WITT, M., REUTTER, K. GANCHROW, D. \& GANCHROW, J. R. (2000) Fingerprinting taste buds: Intermediate filaments and their implications for 
taste bud formation. Philosophical Transactions of the Royal Society of London B. 355, 1233-37.

WITT, M., REUTTER, K. \& MILlER, I.J. JR (2003) Morphology of the Peripheral Taste System. In: Handbook of Olfaction and Gustation (ed. DOTY, R.L.), Marcel Dekker, Inc., New York, Basel, pp 651-677

WRIGHT, M. R. (1964) Taste organs in tongue-to-liver grafts in the newt, Triturus v. viridescens. Journal of Experimental Zoology 156, 377-389.

YASUMATSU, K., KATSUKAWA, H., SASAMOTO, K. \& NINOMIYA, Y. (2003) Recovery of amiloride-sensitive neural coding during regeneration of the gustatory nerve: Behavioral-neural correlation of salt taste discrimination. The Journal of Neuroscience 23, 4362-4368.

YEE, C. L., JONES, K. R. \& FINGER, T. E. (2003) Brainderived neurotrophic factor is present in adult mouse taste cells with synapses. The Journal of Comparative Neurology 459 15-24.

ZALEWSKI, A. A. (1972) Regeneration of taste buds after transplantation of tongue and ganglia grafts to the anterior chamber of the eye. Experimental Neurology 35, 519-528.
ZELENA, J. (1994) Nerves and mechanoreceptors: The role of innervation in the development and maintenance of mammalian mechanoreceptors, Chapman \& Hall, London.

ZENG, Q., KWAN, A. \& OAKLEY, B. (2000) Gustatory innervation and Bax-dependent Caspase-2: Participants in the life and death pathways of mouse taste receptors cells. The Journal of Comparative Neurology 424, 640-650.

ZENG, Q. \& OAKLEY, B. (1999) p53 and Bax: Putative death factors in taste cell turnover, Journal of Comparative Neurology. 413, 168-180.

ZHANG, C., COTTER, M., LAWTON, A., OAKLEY, B., WONG, L. \& ZENG, Q. (1995) Keratin 18 is associated with a subset of older taste cells in the rat. Differentiation 59, 155-162.

ZHANG, C. \& OAKLEY, B. (1996) The distribution and origin of keratin 20-containing taste buds in rat and human. Differentiation 61, 121-128.

ZHANG, C., BRANDEMIHL, A., LAU, D., LAWTON, A. \& OAKLEY, B. (1997) BDNF is required for the normal development of taste neurons in vivo. Neuroreport 8, 1013-1017. 